TEIXEIRA, Faustino; MENEZES, Renata [et al.]. As Religiōes no Brasil: Continuidades e Rupturas. Petrópolis: Vozes, 2006, 264pp.

\title{
RELIGIÕES EM MOVIMENTO: SUBJETIVIDADE E FRONTEIRAS NO CENÁRIO RELIGIOSO BRASILEIRO
}

\section{Christina Vital da Cunha}

A perspectiva teórica que norteia Religiões no Brasil, livro composto por 15 artigos de diferentes antropólogos e sociólogos da religião, refere-se à modernidade e ao seu impacto no campo religioso a partir de uma densa observação das mudanças, articulações, combinações e interpretações da polissemia que caracteriza esse fenômeno no país. Assim, o catolicismo dos novos tempos, os protestantes, pentecostais e neo-pentecostais em expansão e flexibilização, os jovens, o trânsito religioso e os contatos com "os sagrados", os esotéricos e o circuito neo-esotérico, as transformações no campo espírita, as novas falas e atuações públicas dos candomblecistas e umbandistas no Brasil compõem eixos temáticos abordados pelos pesquisadores com base em análises qualitativas e quantitativas pormenorizadamente demonstradas.

O campo religioso brasileiro nunca foi caracterizado, segundo estudiosos da religião, pela constituição de "fronteiras rígidas" entre as diversas formas de crer e de ser religioso. A "porosidade das fronteiras" entre catolicismo e espiritismo formou as instituições religiosas no país, assim como a própria cultura nacional. $\mathrm{O}$ crescimento dos pentecostais de $9 \%$ da população brasileira em 1990, para 15\% em 2000, segundo dados do IBGE, passou, no imaginário social e nas análises de alguns cientistas sociais, a ameaçar o enquadramento sob o qual se estabeleceu o jeito de ser religioso

e mesmo o jeito de ser cidadão no Brasil. $\mathrm{O}$ exclusivismo constitutivo das práticas e da crença evangélica estava em dissonância com a cultura nacional, mas apresentava, desde a época da guinada pentecostal no campo evangélico ao final dos anos 1960 e início dos 1970, um crescimento (para alguns) assustador.

Implicaria esse crescimento numa nova forma de ação social, cultural e política? O passar vagaroso dos anos nos apresenta mais encontros, mais flexibilidade, mais continuidades no cenário religioso brasileiro do que a ruptura (por alguns) temida. O pentecostalismo não acabou com a nossa diversidade. Pelo contrário: o pentecostalismo se tornou mais uma opção no quadro das diversas formas de contato com o sagrado que a sociedade instituiu.

A circulação e mesmo o múltiplo pertencimento, antes impensado, ao catolicismo, ao esoterismo, ao espiritismo e ao pentecostalismo já são observados na 
própria dinâmica da realidade social. $\mathrm{O}$ intenso trânsito religioso pelos textos do livro revelado se apresenta como fruto do voraz processo de individualização da pessoa na modernidade. Os vínculos religiosos apontam para uma experimentação. A fusão das várias crenças numa nova forma de ser fiel a uma religião é resultado das várias experiências religiosas vividas pelo indivíduo. A forma de ser católico, espírita, budista e mesmo evangélico se configura, na modernidade, como o resultado desse percurso de múltiplos contatos com "os sagrados". Existe ainda, neste trajeto, a possibilidade de constituição de uma religiosidade própria, "mixada" a partir das várias ofertas presentes no "mercado religioso" atual. Evidenciam-se assim os chamados "sincretismo tradicional" e "sincretismo pós-moderno".

Ao longo dos textos, é possível captar o intenso contato que os autores promovem entre o "tradicional" e o "moderno". Resignificam e relativizam o que esses "lugares" representam quando o assunto é religião. Nesse sentido, há novas e variadas formas de ser católico, de ser evangélico e mesmo de ser "sem religião" no Brasil contemporâneo.

Religiões no Brasil aborda a questão das crenças, dos costumes, da cultura e das instituições religiosas nacionais numa perspectiva dialógica. As falas presentes nos diferentes capítulos se interrogam, discutem e concluem. Os números estão disponíveis e sua leitura é plurifacetada. Os dados do censo do IBGE de 2000 apontam para um decréscimo do número de católicos acompanhado de um crescimento acentuado do percentual de evangélicos e dos que se declaram "sem religião", assim como do surgimento de variadas expressões religiosas orientais e tradições indígenas. Para alguns analistas esses números demonstram a diversidade religiosa nacional. Chegou-se a 35.000 respostas diferentes no censo. Para outros, os números comprovam não um cenário de diversidade, mas o quanto a religiosidade do brasileiro é marcada pelo cristianismo ou pela perspectiva judaico-cristã. A diversidade de ofertas religiosas existe, mas, em termos de representatividade, a amostra aponta para a concentração de católicos, com 73,8\% das declarações, seguidos pelos evangélicos, com $15,5 \%$ e pelos sem religião, com 7,3\%.

Para falar de católicos, é preciso repensar certa crença na homogeneidade que caracterizaria essa religião. Tal "catolicismo homogêneo" não existiu no Brasil e hoje é ainda mais difícil de ser observado. São muitos os catolicismos que compõem a religião ainda hoje predominante no país: há o catolicismo apostólico romano, o popular, o carismático, o das CEBs e o movimento de Católicas Pelo Direito de Decidir. Tais correntes têm espaços distintos no interior da própria instituição, em decorrência da aceitação política que cada uma delas alcançou.

O catolicismo midiático é ainda outra faceta a se considerar. Muitos cientistas sociais analisam a participação dos evangélicos na mídia e o quanto isso importa em termos da formação de uma nova relação entre os fiéis e suas igrejas. Neste livro, a questão do catolicismo midiático aparece com força e é tratada cuidadosamente a fim de nos apresentar chaves de análise sobre um 
novo modo de ser católico, baseado num "catolicismo rejuvenescido e modernizado" (:81). Se assistir à missa aos domingos caracterizava boa parte dos que se diziam católicos no Brasil, assistir à missa pela televisão e ouvir os programas de rádio pode se consolidar como uma outra forma de ser fiel católico, ou seja, esta forma de "catolicismo eletrônico" compõe o quadro das possibilidades de vivenciar a fé católica contemporaneamente.

O decréscimo percentual de católicos no Brasil veio acompanhado, segundo os autores do livro, de um reavivamento da fé entre os que se declaram fiéis dessa religião. A Renovação Carismática Católica seria a maior expressão dessa nova forma de ser católico no Brasil. A diversidade intrínseca ao catolicismo é comum a outras tantas religiões ao redor do mundo: "É importante, contudo, ressaltar que as demais religiões mundiais são internamente diversas e plurais o islamismo, budismo, confucionismo, entre outras, se expressam das maneiras mais diferentes. Variam muito de uma sociedade para outra, e entre estratos dentro de uma mesma sociedade. A diversidade é constitutiva de outros grupos religiosos que possuem uma amplitude internacional, e não poderia ser diferente" (:57). Novamente observamos um traço marcante da modernidade: o pluralismo. A percepção do pluralismo e da diversidade como valores possibilita a promoção de reconhecimento/aceitação de várias religiões, e, também, de vários movimentos intrínsecos a estas. Exemplo disso seria o RCC, visto que há formas distintas de experimentar ser católico a partir do pertencimento a esse movimento, e, mais ainda, a partir do pertencimento a uma ou outra comunidade que o compõem, como a Comunidade de Vida Canção Nova ou Toca de Assis.

$\mathrm{Na}$ seqüência de encontros, articulações e singularidades do campo religioso, o candomblé nos é apresentado não mais como uma religião própria dos negros, como uma religião étnica e autêntica desse "povo", mas como uma religião universal. Segundo os autores, o candomblé já não se apresenta no espaço público unicamente como a religião dos negros, pois já não teria uma "reserva de mercado de natureza étnica" (:22). O chamado "povo de santo" é composto por uma minoria que se declara negra, segundo pesquisa realizada pelo Datafolha em 1994. Há mais negros que se declaram evangélicos, sobretudo pentecostais, do que no candomblé ou na umbanda. O debate em torno do "lugar" que ocupa o candomblé na cultura e no campo religioso brasileiro percorre as páginas do livro. Para além do discurso de afirmação política da identidade negra, de religião formadora da cultura nacional (que portanto não se assume como de "minoria"), o candomblé hoje ocupa efetivamente o espaço público, juntamente com religiões de outras matrizes, como as orientais, para difundir valores de paz.

Das religiões mediúnicas (umbanda, candomblé e outras expressões "afro") o kardecismo é a que mais tem adeptos declarados, segundo os dados do IBGE 2000. Lê-se nas páginas de Religiões no Brasil que desses autodeclarados kardecistas, há ainda um grande número de autodeclarados "sem religião", ou que declararam 
pertencer a outras religiões que incorporaram elementos do discurso difundido por eles no Brasil, como a noção de "carma" e a de "reencarnação". Os que vagueiam por um circuito religioso sem declarar o pertencimento exclusivo a uma religião, ou que declaram aquelas institucionalmente mais legítimas, elevariam grandemente o índice estatístico dos espíritas de forma geral. Internamente ao campo kardecista, o livro revela uma intensa disputa pela separação do que é "autêntico" daquilo que é "esoterismo" - dito nesse contexto de forma pejorativa. Na atualidade, observase uma difusão da cultura espírita kardecista concomitante a uma lenta "destradicionalização de seus modos de crer e de pertencer" (:186).

Observou-se ainda que as religiões ditas tradicionais poderiam contribuir para o número crescente dos "sem religião". A ruptura com a religião de origem, quando se trata dos católicos, já foi trabalhada em estudos da década de 1980, com destaque para Os Escolhidos de Deus, de Regina Novaes (1985). No entanto, encontramos em Religiões no Brasil a chance de observar o protestantismo como uma religião "tradicional" que, assim como a católica, contribui para o crescimento dos "sem religião": "Distantes das igrejas, muitos oriundos de famílias protestantes ainda se declaram protestantes, mas boa parte já emocionalmente desligados não assumem qualquer religião. Regra geral, não aderem a outras religiões" (:90). Muitos desses que foram criados em famílias protestantes desligam-se da igreja alegando "cansaço de religião", a "solidão da fé" ou a intensa demanda por envolvimento em atividades paroquiais. Fator importante nessa reflexão é ainda o fato de que o protestantismo de imigração ou colonização - o que mais sofre com a expansão dos pentecostais é uma "religião étnica" e como tal tem seus laços religiosos comprometidos com o abandono da língua, dos costumes tipicamente culturais, enfim, do gueto. $\mathrm{O}$ protestantismo “tradicional perde para os 'sem religião' e para as religiões de estilo pós-moderno imediatista" (:91) e, acrescento, individualista.

Em Religiões no Brasil encontra-se problematizada a pertença evangélica. Ser evangélico é ser o quê? O que compõe esse campo? De acordo com o livro em questão, existem três tipos de evangélicos no país: os evangélicos históricos, os evangelicais (são um movimento reunido em torno de instituições de caráter internacional ou continental) e os evangélicos pentecostais. $\mathrm{O}$ "jeito de ser evangélico" relaciona-se diretamente com o pertencimento a uma ou outra dessas correntes.

Mas o entendimento dessa identidade depende ainda da observação da denominação que o fiel congrega ou da trajetória por ele percorrida ao longo de sua experiência cristã, e de que mix realiza - se o faz - no presente. Caracterizar esse campo não é tarefa fácil: "o pentecostalismo brasileiro é considerado pertencente ao meio evangélico ao lado dos protestantes históricos e em oposição ao catolicismo no interior do cristianismo. Mas como classificar, então, os protestantes 'renovados' e os carismáticos católicos que se apropriaram de dimensões do pentecostalismo como a experiência extática da glossolalia e, no caso dos católicos, da conversão individual tipicamente evangélica com ênfase 
na subjetividade e na emotividade? (...) Em resumo, o pentecostalismo extrapola suas fronteiras institucionais assim como incorpora mecanismos de funcionamento de religiões fora do campo cristão." (:111).

A partir desse quadro, seria mais adequado falar em circulação e flexibilidade do que em rupturas e continuidades (:112). Por exemplo, o neopentecostalismo, movimento que se formaria a partir da década de 1970, teria como uma das suas características centrais a assimilação do universo simbólico das religiões afro-brasileiras. O combate a essas religiões estaria, assim, baseado na intenção de monopolizar seu principal bem "no mercado religioso, as mediações mágicas e a experiência do avivamento (em forma de êxtase religioso)" (:208). Dessa, forma, o combate às religiões afro-brasileiras estaria ligado não somente a uma tentativa de retirar dessa fé e transpor para os bancos das igrejas os candomblecistas e umbandistas "arrependidos", mas, principalmente, de atrair toda espécie de indivíduo ávido pela experiência mágica e extática com a vantagem da legitimidade social da qual desfrutam os cristãos no Brasil. A experiência do transe religioso estaria na fronteira fluida entre as religiões afro e as igrejas neo-pentecostais.

Muitos encontros entre evangélicos pentecostais e o "povo de santo" são salientados nesta obra, como os aspectos rituais e dogmáticos. Gostaria de ressaltar ainda outro ponto em comum: os dois aceitam os indivíduos da "margem" social. No entanto, as religiões afro-brasileiras aceitam a "margem" para consagrar o seu poder contestador. "Já no neo-pentecostalismo abraça-se a todos os estigmatizados e marginais com a promessa de libertá-los de seus exus-demônios e curá-los. Afinal, a conversão da 'margem' valoriza o 'centro' (:225)".

A circulação do evangélico no interior do próprio campo é observada também como uma forma contemporânea onde a subjetividade compõe a forma através da qual se quer ser evangélico. Com essa movimentação é possível ser menos atingido pelas diversas formas de controle exercidas pela "comunidade". "As circulações de conteúdos religiosos e de pessoas não se sobrepõem pari passu, mas são correlatas, e elas conferem aos pentecostais e a alguns evangélicos nãopentecostais um dinamismo intenso e uma ampla elasticidade em que a religiosidade é vivida de maneira mais alargada do que aquela confessada pelo indivíduo" (:117). Em outras palavras, seriam a circulação e a flexibilidade características próprias do pentecostalismo contemporâneo. São numerosos também aqueles que declaram um duplo pertencimento: em primeiro lugar se identificam como fiéis católicos e em segundo lugar como fiéis evangélicos.

Num contexto de mundialização, de individualismo crescente, de multiplicidade de opções e, por fim, de pluralismo religioso, escolher uma religião pode caracterizar cada vez mais um rompimento com o passado religioso familiar, como já foi salientado. Tais rupturas biográficas podem "resultar num rompimento mais geral com o passado histórico do Brasil como "nação católica”' (:19). Nessa 
perspectiva, a religião de origem representa para a sociologia da religião um objeto de análise menos instigante e menos rentável analiticamente do que a religião de escolha.

A análise da vivência das religiões pelos jovens no Brasil hoje exige "inovações teóricas e muita pesquisa de campo" (:137). A busca de emancipação do jovem atinge contemporaneamente os vínculos religiosos. Ou seja, no processo de afirmação de uma identidade própria, dá-se o processo de distanciamento dos vínculos religiosos originados na família, ainda que esse distanciamento seja apenas momentâneo, um hiato entre "tradição" e escolha. Para a juventude há três tendências que se fazem presentes: o intenso trânsito religioso, acompanhado de uma ampla abertura para novas combinações sincréticas; a diminuição da absorção dos padrões religiosos familiares; e a possibilidade de experimentar e desenvolver a religiosidade sem vínculos institucionais obrigatórios. E a busca de novas experiências religiosas "não está livre do consumismo, do modismo, do individualismo ou simplesmente da alienação presente na sociedade. Mas nesta mesma busca, também, pode predominar a afirmação da ética, da ecologia, da paz e do pertencimento religioso como lócus de agregação social” (:159).

Religiões no Brasil apresenta uma profícua discussão sobre o significado da declaração "sem religião": ela poderia expressar uma ruptura com a religião familiar; um interstício entre a mudança de um padrão religioso institucional para outro; a absorção de variados padrões religiosos sem o necessário vínculo institucional; a crença em elementos simbólicos da New Age. No entanto, as análises nos conduzem a pensar a declaração "sem religião" como uma possibilidade contemporânea de experimentar, ou melhor, de construir experiências religiosas de forma subjetivada e sem a necessidade do suporte institucional. A fidelidade ou exclusividade religiosa como valor é atualizada: o ethos da opção religiosa se comunica intrinsecamente com o ethos da modernidade onde o padrão de "verdade" é substituído pelo que "serve", o que dá prazer, o que dá respostas às questões colocadas num determinado momento. É como se "uma nova ótica, a do consumo, se interpusesse entre o indivíduo e a instituição religiosa" (:129). O que se percebe é o trânsito entre crenças/visões de mundo/teodicéias e não, exclusiva e necessariamente, entre instituições. Contemporaneamente é possível perceber a busca de um sentido religioso para a vida, mas não é mais a identidade religiosa institucional que produz o sentido ou as "imagens do mundo" (:135).

O repertório de crenças e práticas conhecidas como esotéricas, alternativas, da Nova Era, etc., identificadas também como uma espécie de religião à la carte, a self made religion (:162), compõe um quadro expressivo dos "ventos pós-modernos que então bafejam" (:162): esse conjunto de crenças seria caracterizado como uma nova forma de consciência religiosa marcada pela reflexividade, pelo cultivo do eu e pelo movimento de "destradicionalização". Ao longe, esse universo esotérico apresenta uma enorme fragmentação e amplitude. Entretanto, nas 
condições atuais de sua implantação na cidade, os circuitos "neo-esotéricos" mostram um intenso poder de mobilização e de promoção de rotinas/estilo de vida, de construção de vínculos fortes no interior dos grupos, também chamados de "comunidades efêmeras" (:168), e de criação de valores e formas de sociabilidade para os que utilizam regularmente determinados bens e serviços "alternativos". Se, por um lado, a fragmentação que impedia a formação de um estilo de vida, de valores e padrões de consumo já não é necessariamente uma característica do campo esotérico nas cidades, por outro, a diversidade do discurso no interior desse campo ainda é uma marca.

Os autores citam lideranças e correntes esotéricas para exemplificar a complexidade que tal diversidade discursiva oferece para o pesquisador desse tema. Segundo alguns estudiosos da religião, a aproximação entre o ethos da modernidade e o ethos New Age teria como corolário o crescimento dos esotéricos em detrimento das religiões institucionalizadas. No entanto, o que se observa é que estas crenças e tradições convivem com outras religiões sem lhes tomar o lugar e sem exigir de seus praticantes exclusividade. A aproximação com a ciência ou a incorporação do discurso das várias ciências na legitimação e fomento de crenças e práticas é também uma característica da Nova Era.

Enfim, a perspectiva que corta transversalmente os capítulos de Religiões no Brasil refere-se à intensa valorização da experiência religiosa individual que se comunica umbilicalmente com a influência dos discursos individualistas presentes na modernidade. Em outras palavras, no Brasil contemporâneo podem ser observadas variadas formas de experimentação do sagrado. As trocas características da mundialização em curso proporcionam a existência de novas formas de "ser religioso" com pertencimentos antes não imaginados. Acredito ser esse um dos grandes méritos deste livro: o de desmistificar visões e possibilitar ao leitor uma aproximação com casos reveladores de uma nova forma de ter uma religião no Brasil.

Christina Vital da Cunha (chrisvital@uol.com.br) Doutoranda em Antropologia pelo PPCIS/UERJ, pesquisadora da área de Religião e Sociedade do ISER, membro do Laboep/Feuff - Laboratório de Educação Patrimonial da UFF, coordenadora de conteúdo do site Favela Tem Memória e membro da equipe de pesquisa sobre a atuação do Exército Brasileiro na Missão de Paz da ONU no Haiti. 